\title{
Prion Protein at the Leading Edge: Its Role in Cell Motility
}

\author{
Mariana Brandão Prado ${ }^{\dagger}$, Maria Isabel Melo Escobar ${ }^{\dagger}$, Rodrigo Nunes Alves $^{\dagger}$,

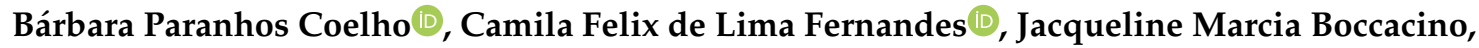 \\ Rebeca Piatniczka Iglesia and Marilene Hohmuth Lopes * (D)
}

Department of Cell and Developmental Biology, Institute of Biomedical Sciences, University of São Paulo, São Paulo 05508-000, Brazil; mariana.brandao.prado@usp.br (M.B.P.); isabelmelo@usp.br (M.I.M.E.); rodrigo.nunes.alves@usp.br (R.N.A.); coelhobarbarap@usp.br (B.P.C.); camila.felix@icb.usp.br (C.F.d.L.F.); jacquelineboccacino@usp.br (J.M.B.); rebecapi@usp.br (R.P.I.)

* Correspondence: marilenehl@usp.br

+ These authors contributed equally for this work.

Received: 1 August 2020; Accepted: 9 September 2020; Published: 12 September 2020

\begin{abstract}
Cell motility is a central process involved in fundamental biological phenomena during embryonic development, wound healing, immune surveillance, and cancer spreading. Cell movement is complex and dynamic and requires the coordinated activity of cytoskeletal, membrane, adhesion and extracellular proteins. Cellular prion protein $\left(\mathrm{PrP}^{\mathrm{C}}\right)$ has been implicated in distinct aspects of cell motility, including axonal growth, transendothelial migration, epithelial-mesenchymal transition, formation of lamellipodia, and tumor migration and invasion. The preferential location of $\mathrm{PrPC}^{\mathrm{C}}$ on cell membrane favors its function as a pivotal molecule in cell motile phenotype, being able to serve as a scaffold protein for extracellular matrix proteins, cell surface receptors, and cytoskeletal multiprotein complexes to modulate their activities in cellular movement. Evidence points to $\mathrm{PrP}^{\mathrm{C}}$ mediating interactions of multiple key elements of cell motility at the intra- and extracellular levels, such as integrins and matrix proteins, also regulating cell adhesion molecule stability and cell adhesion cytoskeleton dynamics. Understanding the molecular mechanisms that govern cell motility is critical for tissue homeostasis, since uncontrolled cell movement results in pathological conditions such as developmental diseases and tumor dissemination. In this review, we discuss the relevant contribution of $\mathrm{PrP}^{\mathrm{C}}$ in several aspects of cell motility, unveiling new insights into both $\mathrm{PrP}^{\mathrm{C}}$ function and mechanism in a multifaceted manner either in physiological or pathological contexts.
\end{abstract}

Keywords: prion protein; cell motility; adhesion; metastasis; invasiveness

\section{Introduction}

Cell motility is a fundamental process that entails intracellular remodeling, an intricate molecular network, and several cell-milieu interactions [1]. Motile cells are essential for several biological events, such as morphogenesis [2], angiogenesis [3], muscle contraction [4], vesicle transport [5], wound healing [6] and immune response, as well as for pathological events. Most cell types in different tissues are capable of migrating on a substrate, and cellular locomotion is governed by different processes [7]. Actin represents one of the main proteins in the cytoskeleton and its polymerization is key in the assembly and dynamic behavior of microfilaments [8]. Those microfilaments play a major role in the generation of cell polarity, since they are responsible for the formation of dynamic membrane protrusions of the cell edge, such as lamellipodia, filopodia, cell cortex, microvilli, as well as stress fibers that generate focal adhesions (FA) to the substratum, and in cytokinesis for cell division [9]. 
Cell migration capacity is of great importance not only for the correct function of the organism, but also for development, remodeling of adult tissue, and wound healing [10].

Abnormal cell motility contributes to a number of illnesses such as neuronal development disorders, immunodeficiency, cancer, and neurodegenerative diseases [11]. In cancer, the migration of tumor cells leads to invasion and metastasis-both processes being crucial for tumor development and poor response to treatment, and decisive for patient survival [12].

Cellular movement phenomena require the orchestration of numerous extra- and intracellular multiprotein complexes, and the cellular prion protein $\left(\operatorname{PrP}^{C}\right)$, a cell membrane molecule, seems to have a pivotal role in cell movement in several aspects. $\operatorname{Pr} P^{C}$ is encoded by the PRNP gene, and its expression is detected very early in the post-implantation embryo [13], being involved in the regulation of different mammalian stem and progenitor cell proliferation and differentiation mechanisms [14]. $\mathrm{PrP}^{\mathrm{C}}$ is expressed in neurons and in most neural cell types, modulating astrocyte development [15], oligodendrocyte proliferation [16], and proper functioning of microglia in early stages [17]. Besides the central nervous system (CNS), $\operatorname{PrP}^{\mathrm{C}}$ is also expressed in cells of the peripheral nervous system (PNS) [18], as well as in organs and tissues of other systems, such as the heart, intestine and pancreas [19].

$\operatorname{PrP}^{\mathrm{C}}$ is organized into two main domains: a less flexible $\mathrm{C}$-terminal domain of globular structure, with a glycophosphatidylinositol (GPI) membrane anchor [20-22], and a flexible and less organized $\mathrm{N}$-terminal domain containing octapeptide repeats [23,24], closely related with the binding of $\operatorname{PrPC}$ to a number of protein partners $[25,26]$. $\mathrm{PrP}^{\mathrm{C}}$ is located on lipid rafts, which are cholesterol-rich portions of the cell surface highly associated with activation of signaling cascades [27], and can couple with plenty of membrane receptors located in these niches, forming multiprotein signaling platforms [27-29]. $\mathrm{PrP}^{\mathrm{C}}$ ligands in the physiological and pathological contexts include transmembrane proteins, ion channels, extracellular matrix proteins and several secreted molecules including stress inducible protein 1 or heat shock organizing protein (STI1/HOP) [30-33]. The major $\operatorname{PrP}^{\mathrm{C}}$ ligands described are molecules related to adhesion and migration processes, such as neural cell adhesion molecule 1 (NCAM1), laminin, and laminin receptors [27]. Indeed, recent data from our group have shown that the modulation of $\operatorname{PrP}^{\mathrm{C}}$ expression can affect E-cadherin recruitment to the surface and cell migration in glioblastoma stem cells [31], demonstrating a relevant involvement of $\operatorname{PrP}^{\mathrm{C}}$ in these processes. $\mathrm{PrP}^{\mathrm{C}}$ also plays an important role in cell adhesion during zebrafish gastrulation [34] and migration of brain endothelial cells [35], forms adherens junction (AJ) with E-cadherin and F-actin in epithelial cells [36] and induces reorganization of the actin cytoskeleton in human T cells [37], among other hallmark features related to the motility of several types of cells.

This review discusses the biological processes involved in cell motility and migration, highlighting the participation of $\mathrm{PrP}^{\mathrm{C}}$ as a signaling organizer in these mechanisms for the proper functioning of cells under physiological conditions, as well as in the progression of cancer, focusing on $\operatorname{PrPC}^{\mathrm{C}}$ as a player in invasion and metastasis events of several types of neoplasm.

\section{Prion Protein in Dynamic Cell Movement}

Functional components that actively participate in several aspects of cell motility processes are located on dynamic multi-molecular platforms on the plasma membrane. $\operatorname{PrP}^{\mathrm{C}}$, a versatile protein with scaffold property, represents a potential molecule able to orchestrate the activity of signaling modules on the cell membrane involved in cellular migration. In this section, we discuss the pivotal role played by $\operatorname{PrP}^{\mathrm{C}}$ in modulating different motility phenomena, highlighting its interaction with proteins that regulate cell-cell and cell-matrix adhesion, as well as other novel partners in the context of the multi-step migration process.

As previously mentioned, $\operatorname{PrP}^{\mathrm{C}}$ expression is high in the CNS and PNS, where its function has been extensively studied. The role played by $\mathrm{PrP}^{\mathrm{C}}$ in the control of synapses, myelination, neuronal survival, and differentiation conceive this protein as a prominent neurotrophic modulator [30,38,39]. Following differentiation, neuron cells attach to the extracellular matrix (ECM) and start to project cytoplasmic extensions of the cell body, called neurites, in order to migrate [40]. $\mathrm{PrP}^{\mathrm{C}}$ modulates neurite 
outgrowth and neuronal survival when secreted as a soluble molecule, working as a ligand for signal transduction proteins $[30,41]$. The neurite growth process, in turn, requires cytoskeleton remodeling, and complete depletion of $\mathrm{PrP}^{\mathrm{C}}$ leads to $\beta 1$ integrin aggregation, FA turnover, and increased stability of actin filaments, ultimately resulting in impaired neurite sprouting [42]. FA comprises structures rich in cell adhesion molecules (CAMs) such as integrin, an $\alpha / \beta$ heterodimeric adhesion glycoprotein receptor that clusters when bound to its ligand, thereby forming multiprotein complexes for intracellular signaling and actin cytoskeleton remodeling [43]. Moreover, FA formation is regulated by Ras homolog family member A (RhoA) activity which, in turn, is modulated by c-Src and focal adhesion kinase (FAK) proteins [44,45]. Additionally, $\mathrm{PrP}^{\mathrm{C}}$ signaling has been suggested to impact axon guidance.

Growth cones are essential for guiding the process of neurite sprouting, which is fundamental for the morphogenesis of the nervous system [46]. The growth cone per se is divided into two regions: the central domain, rich in microtubules and other associated proteins, and the peripheral domain, rich in actin filaments [47]. The polymerization of those filaments results in lamellipodia and filopodia-like protrusions with membrane receptors at their tips, sensing a variety of extracellular factors of the environment that act as guidance cues for this process [48]. $\mathrm{PrP}^{\mathrm{C}}$ was found to be accumulated at the tip of filopodia in growth cones and in cell-cell connection sites. It has been observed that the upregulation of the protein in these specific sites is accompanied by growth cone extension and formation of $\mathrm{AJ}$ and nanotubes [49]. In agreement, challenging the notion that $\operatorname{PrP}^{\mathrm{C}}$ knockout $(\mathrm{KO})$ had no major deleterious effects in early mouse embryos [50], Bradikov and collaborators showed that hippocampal neurons lacking $\operatorname{PrP}^{\mathrm{C}}$ had smaller neurites and growth cones [51]. More specifically, $\operatorname{PrP}^{\mathrm{C}}$ is able to cluster in reggie membrane microdomains [52], activating the Src-kinase Fyn and Mitogen-activated protein kinase (MAPK), dynamically regulating the polarized transport of membranes and membrane proteins, such as N-cadherin, to the growing tip of neurons [51] (Figure 1). This turnover of membranes and membrane proteins in the growth cone is a fundamental step to the correct targeting and subsequent elongation of neurites towards the right direction of impulse, ensuring correct nerve cell connections [53]. In addition, it is known that the activation of integrin receptors may cause an influx of $\mathrm{Ca}^{2+}$ that affects membrane trafficking and reorganization of the growth cone [54]. $\mathrm{PrP}^{\mathrm{C}}-\mathrm{KO}$ leads to a reduction in the number and trafficking of vesicles containing $\mathrm{N}$-cadherin, an important component of $\mathrm{AJ}$, diminishing $\mathrm{N}$-cadherin association with reggie microdomains and resulting in impaired downstream signaling, ultimately leading to smaller growth cone and elongation failure [51].

$\operatorname{PrPC}$ function in the growth cone appears to be dependent, in some instances, on the well-established ability of the protein in binding copper ions. Using focal neurite stimulation, a technology that enables access to the effect of soluble recombinant $\operatorname{PrP}^{\mathrm{C}}$ molecules released locally in a single growth cone, researchers have described that $\operatorname{PrP}^{\mathrm{C}}$ can function as a ligand, binding the GPI-anchored form of the protein and initiating a signaling cascade that activates actin remodeling in the periphery of growth cone [55]. More recently, the same research group showed that mutations in distinct copper-binding regions of $\mathrm{PrP}^{\mathrm{C}}$ impaired neurite outgrowth and growth cone rapid navigation, possibly impacting axonal guidance [56].

The presence of some contrasting evidence on $\mathrm{PrP}^{\mathrm{C}}$ function for neurite outgrowth is worth noting. A report by Davanathan et al. shows that $\operatorname{PrP}^{\mathrm{C}}$ may have a negative effect on neurite sprouting through its interaction with Reelin, a glycoprotein with proteolytic activity, and the contactin-associated protein (Caspr), a novel binding partner of $\mathrm{PrP}^{\mathrm{C}}$ [57]. In this model, $\mathrm{PrPC}^{\mathrm{C}}$ inhibits Reelin's proteolytic function, protecting Caspr through direct interaction, maintaining its inhibitory effect on neurite growth [57]. These authors argue that this evidence does not contradict previous work that suggests that $\operatorname{PrPC}$ influences neurite growth, but rather advocate that $\operatorname{PrP}^{C}$ is a regulator of environmental cues of the CNS that balances between neurite outgrowth promotion and inhibition, acting as a positive modulator of this process only in the absence of Caspr activity [57]. A more in-depth study on the signaling behind the observed phenotypes is required to improve the understanding of the proposed role of $\operatorname{PrP}^{\mathrm{C}}$ in inhibiting neurite sprouting since several different reports have pointed to its role in promoting neurite formation, with strong experimental signaling evidence. 


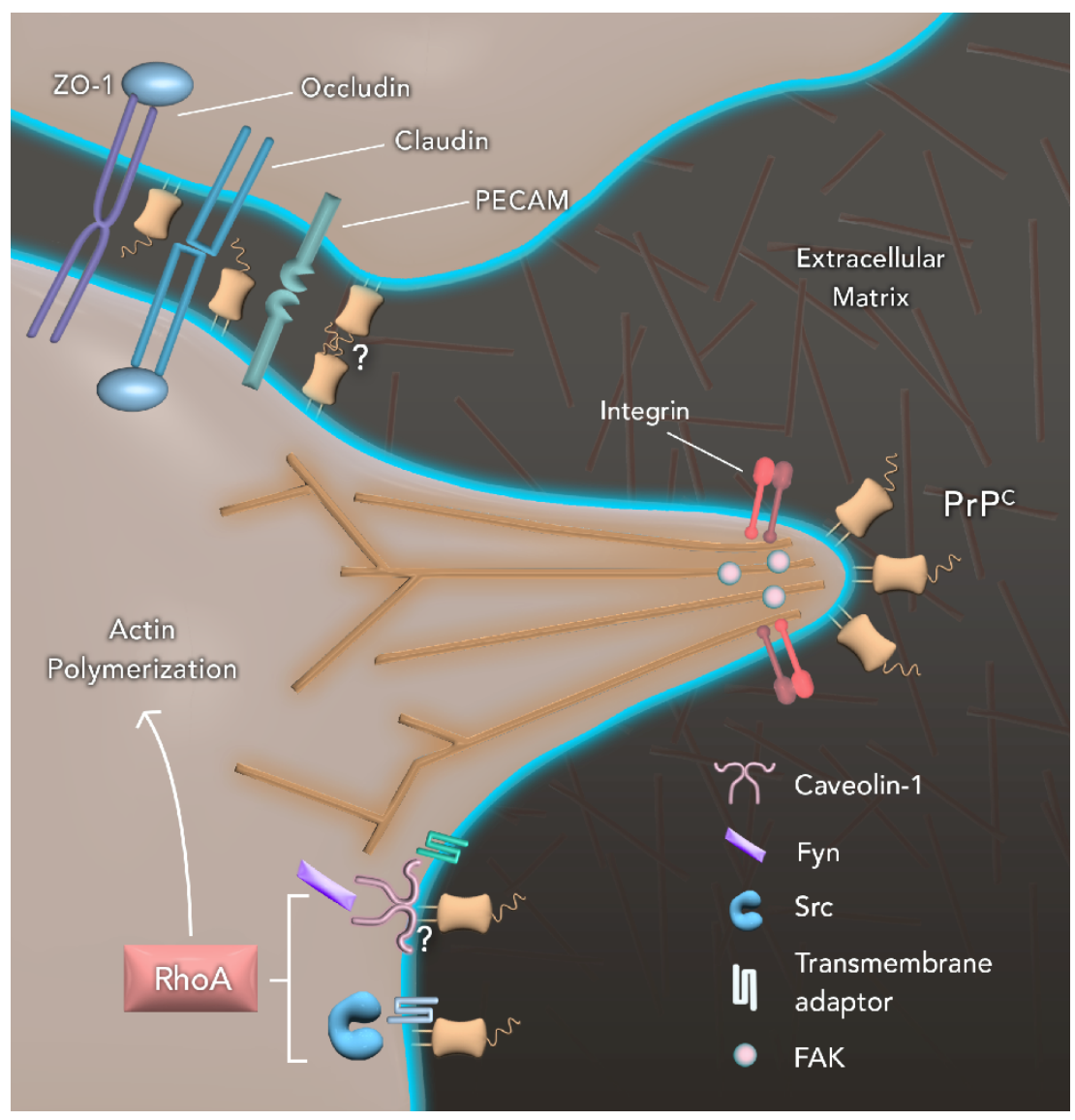

Figure 1. Cellular prion protein $\left(\mathrm{PrP}^{\mathrm{C}}\right)$ participates in cell motility through interaction with several partners. $\mathrm{PrP}^{\mathrm{C}}$ can promote the activation of Fyn in a caveolin-1-dependent manner, although the exact mechanism is unknown. Additionally, $\mathrm{PrPC}^{\mathrm{C}}$ can also modulate the activation of Scr. Since $\mathrm{PrPC}^{\mathrm{C}}$ is a glycophosphatidylinositol (GPI)-anchored protein and all the aforementioned proteins are cytosolic, it is postulated the existence of a transmembrane adaptor that acts as an intermediator. Both Fyn and Src are essential for the regulation of Ras homolog family member A (RhoA) activity. In turn, RhoA has a role in the actin polymerization and assembly of F-actin, as well as the formation of cell protrusions such as focal adhesions (FA) with the presence of focal adhesion kinase (FAK), a central regulator of FA. At the tip of FAs is observed an agglomeration of $\mathrm{PrP}^{\mathrm{C}}$, as well as integrins and, since $\operatorname{PrP}^{\mathrm{C}}$ is known to interact with molecules from the extracellular matrix (ECM), it is postulated that both proteins have an important role in adhesion to the extracellular matrix during cell movement. Additionally, $\mathrm{PrP}^{\mathrm{C}}$ is also known to modulate adhesiveness, being found at the tip of FA and co-localizing with key proteins in cell-cell adhesion domains such as occludin, claudin, PECAM and ZO-1. It is not yet clear if $\operatorname{PrP}^{\mathrm{C}}$ can interact homophilically with other $\mathrm{PrP}^{\mathrm{C}}$ molecules from the neighboring cells, although a co-localization is observed.

As previously mentioned, interaction with a large number of partner proteins is a relevant aspect of $\mathrm{PrP}^{\mathrm{C}}$ function, not only in the CNS, but also in other tissues. STI1 is among the best-characterized $\mathrm{PrP}^{\mathrm{C}}$ ligands. This is a well-described co-chaperone that can be secreted by different cells, including astrocytes, and that binds PrPC extracellularly [58]. PrPC-STI1 interaction protects cells from the toxic effects of staurosporine-induced cell death through Protein kinase A (PKA) signaling and promotes neuritogenesis through the MAPK signaling pathway [59] (Figure 2). It has recently been demonstrated that specific point mutations that disrupt the PrPC_STI1 complex partially or completely impaired neuritogenesis and neuroprotection activity [60], and that STI1 treatment prevented neuronal apoptosis and cell death in a $\mathrm{PrP}^{\mathrm{C}}$-dependent manner [61]. Although STI1 is a known PrPC partner, the PrPC_STI1 complex has not been closely studied in the context of cell motility, despite evidence of its importance. 
Murine STI1 has been shown to strongly and specifically bind F-actin through its TPR2A and TPR2B domains, which interestingly are also $\mathrm{PrP}^{\mathrm{C}}$ binding sites [62]. Given the high degree of evolutionary conservation of $\mathrm{PrP}^{\mathrm{C}}$ and STI1, their wide distribution in different cell types and the data gathered here, the PrPC $\mathrm{P}^{\mathrm{C}} \mathrm{STI} 1$ complex may regulate processes associated with cell migration, thus requiring further investigation.

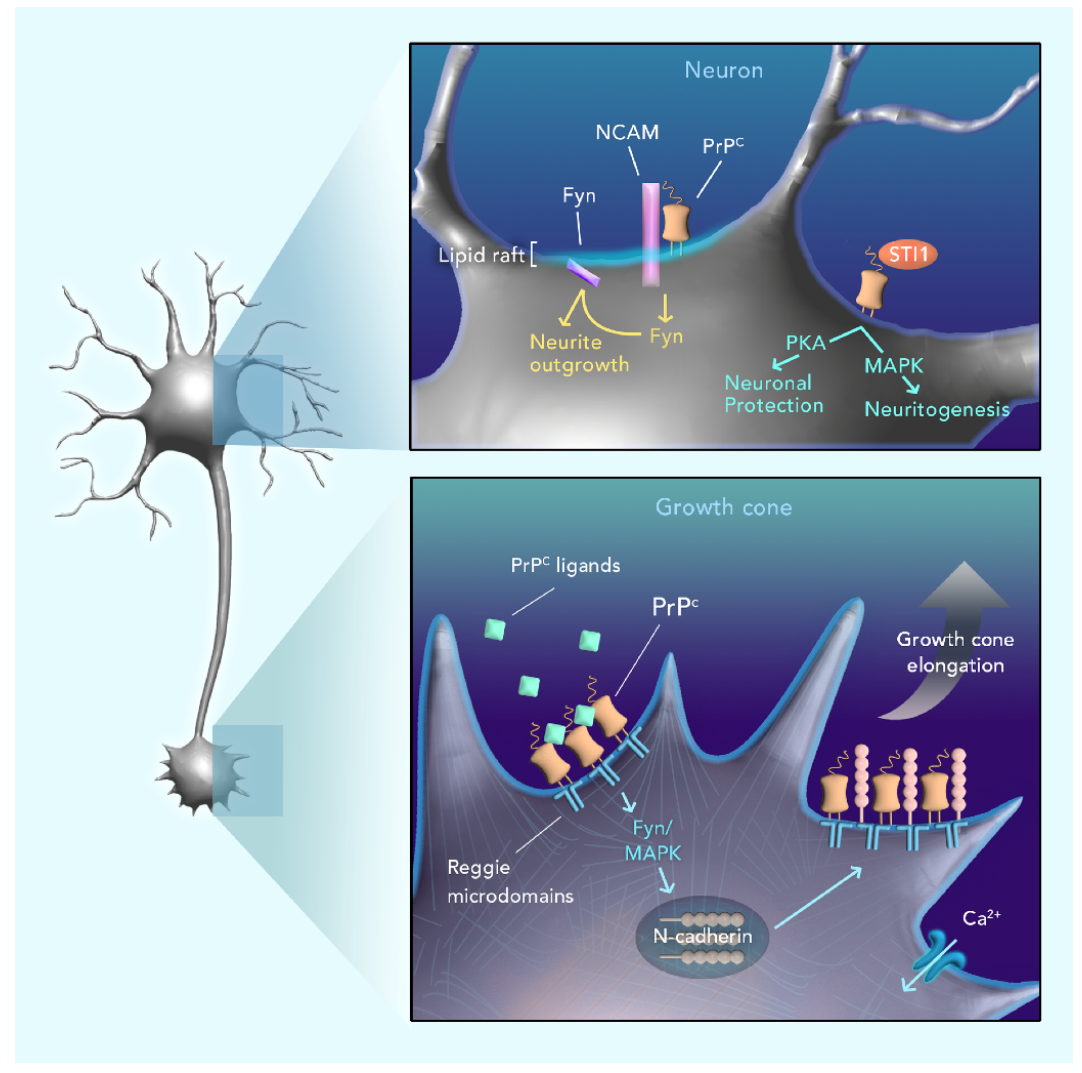

Figure 2. Role of $\operatorname{PrP}^{\mathrm{C}}$ in neuronal plasticity. Upper panel: $\operatorname{PrP}^{\mathrm{C}}$ seems to interact with neural cell adhesion molecule (NCAM), promoting the recruitment of Fyn to lipid rafts and stimulating neurite outgrowth. Additionally, $\operatorname{PrP}^{\mathrm{C}}$ interaction with its well-known ligand, STI1, is able to modulate both Protein kinase A (PKA) and Mitogen-activated protein kinase (MAPK) pathways. The first one is shown to promote neuronal protection, while the second one promotes neuritogenesis. Lower panel: $\mathrm{PrPC}^{\mathrm{C}}$ activated through a ligand or through antibody-mediated crosslinking is able to cluster in reggie microdomains, promoting the activation of Fyn and MAPK. Both of those proteins have an important role in the polarized transport of N-cadherin to regions of growth cone elongation, where it associates with reggie. Additionally, $\mathrm{Ca}^{2+}$ intake is also important to the modulation of this process.

Recently, Song and collaborators addressed the role of another possible partner protein, Thymosin Beta 4 (T $\beta 4$ ), in the deregulation of the cytoskeleton dynamics due to $\operatorname{PrP}^{\mathrm{C}}$ dysfunction [63]. $\mathrm{T} \beta 4$ blocks the polymerization of actin, providing a pool of monomers and functioning on the assembly of the actin filaments [63]. It was observed that $T \beta 4$ mitigates the effects of infection by a $\mathrm{PrP}$ amyloidogenic region. T $\beta 4$ treatment increased cell viability, reduced the F-actin/G-actin ratio, and induced the expression of zonula occludens 1 (ZO-1) and occludin, which are proteins found in tight junctions. It is not clear, however, whether $\mathrm{T} \beta 4$ acts with $\mathrm{PrP}^{\mathrm{C}}$ directly, or indirectly through partner proteins [63].

In mammalian brain endothelial cells (BEC), localization of $\operatorname{PrP}^{\mathrm{C}}$ in cell-cell contacts is dependent on the expression of the protein by two adjacent cells, where it strongly co-localizes with PECAM-1 [35]. $\mathrm{PrP}^{\mathrm{C}}$ expression increased cell spreading and filopodia formation in Drosophila and N2a cells [64]. 
Further, $\mathrm{PrP}^{\mathrm{C}}$ accumulates at the tips of these protrusions, co-localizing with known FA markers, such as phosphorylated-Src and reggie-1. PrPC knockdown (KD) regulates FA dynamics, leading to a reduction in FA number and an increase in FA size [64]. In polarized intestinal epithelial cells, $\operatorname{PrPC}$ was preferentially expressed in cell-cell adhesion sites, interacting with actin and Src proteins [65] (Figure 1). Remarkably, $\mathrm{PrP}^{\mathrm{C}}$ is not only important for the formation of protrusions and cell-cell and cell-matrix contact in nerve cells, but also for other types of cells and tissues.

In zebrafish, $\operatorname{PrP}^{\mathrm{C}}$ was expressed specifically in sites of trans-homophilic interactions $\left(\mathrm{PrP}^{\mathrm{C}}-\mathrm{PrP}^{\mathrm{C}}\right)$ [34]. Zebrafish contains the PrP-1 and PrP-2 genes, which are duplicated PrP genes as compared with mammalian $\operatorname{PrP}^{\mathrm{C}}$ [66]. PrP-1 is ubiquitously expressed at early midblastula stages, while PrP-2 transcripts reach high expression levels in the brain around $30 \mathrm{~h}$ post-fertilization [34]. PrP-1 KD in zebrafish embryos resulted in developmental arrest, and this phenotype is explained by the loss of embryonic cell adhesion during gastrulation [34]. Additionally, $\operatorname{PrP}^{\mathrm{C}} \mathrm{KD}$ interfered in the cellular localization of the E-cadherin and $\beta$-catenin migration-related proteins and in the disorganization of F-actin in a $\mathrm{Ca}^{+2}$-dependent pathway in different model organisms [34], once more indicating evolutionarily conserved cell adhesion and motility roles. Accordingly, Huc-Brandt and collaborators reported that, during the collective migration process in zebrafish primordium and in neuromast formation, PrP-2 KO results in E-cadherin and $\beta$-catenin mislocalization and loss of cell cohesion [67].

In 2011, a study reported the first direct evidence of $\operatorname{PrP}^{\mathrm{C}}$ modulation in the migration of mouse brain microvascular endothelial cells (BMVEC). A study showed that siRNA downregulation of $\operatorname{PrPC}$ resulted in a reduction of approximately $18 \%$ in migrating cells compared with controls, covering an area approximately $9 \%$ smaller [68].

Both in zebrafish and mammals, one way through which $\operatorname{PrP}^{\mathrm{C}}$ modulates cell adhesion and controls dynamics of the actin cytoskeleton is by stimulation of Src-related kinases and its targets. In epithelial cells of the digestive tract, $\mathrm{PrP}^{\mathrm{C}}$ forms $\mathrm{AJ}$ with E-cadherin and F-actin while also co-localizing with Src-kinase [36]. In human enterocytes, $\mathrm{PrP}^{\mathrm{C}}$ interacts with proteins of the Src kinase family, such as Fyn and Src. PrPC activates Fyn through a caveolin-1-dependent coupling [69] and Src through direct physical interaction [36] (Figure 1). Moreover, in human $\mathrm{T}$ cells, $\mathrm{PrP}^{\mathrm{C}}$ can induce reorganization of the actin cytoskeleton through the Src-related kinases Fyn and Lck and increase the levels of intracellular $\mathrm{Ca}^{2+}$ [37]. In zebrafish embryos, PrP-1 buildup at cell contacts elicited similar signaling events [34]. However, in lymphocytes, activated $\mathrm{PrP}^{\mathrm{C}}$ was found in reggie raft microdomains instead of caveolae [37]. Therefore, the spatial localization of $\mathrm{PrPC}^{\mathrm{C}}$ in microdomains of the plasma membrane might dictate the distribution of Src family signaling partners and consequent activation of different cellular events.

Another way $\operatorname{PrP}^{C}$ appears involved with cell-cell adhesion is through interactions with desmosomal proteins, and this has been demonstrated both in enterocytes and BMVEC [70,71]. Intestine from $\mathrm{PrP}^{\mathrm{C}} \mathrm{KO}$ mice and Caco-2/TC7 enterocytes showed increased paracellular permeability and impaired cellular junctions [71]. Cultures from $\operatorname{PrP}^{\mathrm{C}} \mathrm{KD}$ cells exhibited altered morphology and cell junctions, in addition to decreased levels of E-cadherin and the desmosomal proteins desmoplakin, plakoglobin, claudin-4, occludin, ZO-1 and tricellulin at cell contacts [71]. Interestingly, $\mathrm{PrP}^{\mathrm{C}}$ levels were decreased at cell junctions in epithelia from the colon of patients with Crohn's disease or ulcerative colitis [71]. In BMVEC, $\operatorname{PrP}^{\mathrm{C}} \mathrm{KD}$ decreased the expression of occludin and claudin-5, leading to augmented permeability in monolayer cultures [70].

$\operatorname{PrP}^{\mathrm{C}}$ also seems to affect protein interactions in the plasma membrane through the regulation of integrin microclustering and adhesion during monocyte migration. In order to migrate through the endothelium, a process also known as transendothelial migration (TEM) is used, where integrins present in microclusters in the leukocyte plasma membrane bind endothelial ICAM-1 and VCAM-1 receptors, generating strong adhesion to the endothelium [72]. This strong adhesion allows leukocytes to withstand flow-induced detachment and initiate tissue extravasation [72]. This process requires 
integrins to cluster upon ligand binding, which intensifies avidity and reinforces adhesiveness. Integrin clustering, in its turn, can only occur after its release from the actin cytoskeleton [72,73].

$\mathrm{PrP}^{\mathrm{C}}$ seems to regulate ligand-induced changes during integrin activation, thus controlling $\beta 1$-integrin adhesion. $\mathrm{PrP}^{\mathrm{C}}$ silencing induces cofilin 1 inactivation. This inactivation occurs through phosphorylation on cofilin 1 Ser3 by LIM kinase, which is activated by RhoA [74]. RhoA is able to bind to actin-binding proteins and regulate the assembly of F-actin and the formation of a lamellipodium, a cytoplasmic protrusion involved in cell locomotion [75]. Cofilin 1 severs actin filaments, in addition to depolymerizing F-actin, generating new actin monomers for polymerization [76]. Therefore, in $\mathrm{PrPC}^{\mathrm{C}}$-deficient cells, the release of activated integrins from the cytoskeleton is prevented, because RhoA-induced cofilin inactivation sustains the stabilization of actin filaments. Ultimately, this hinders integrin microclustering and avidity for its endothelial targets [74]. This is supported by findings of RhoA activation and consequent cofilin inactivation in $\mathrm{PrP}^{\mathrm{C}}$-deficient neuronal cells, which increase cytoskeletal stability [77]. In line with this, primary rat hippocampal neurons overexpressing $\mathrm{PrP}^{\mathrm{C}}$ showed increased cofilin activation and formation of actin-cofilin rods [78], whereas mice overexpressing $\operatorname{PrP}^{\mathrm{C}}$ showed altered ex vivo thymocyte laminin-induced migration [79].

Moreover, $\operatorname{PrP}^{\mathrm{C}}$ silencing also altered uropod formation in monocytes possibly by inhibiting phosphorylation of proteins of the ezrin, radixin and moesin (ERM) family. The uropod is a structure with adhesive properties that forms on one edge of the migrating leukocyte during cell polarization. This specialized structure contains cholesterol-rich membrane domains, $\beta 1$ integrins, and other adhesion receptors, in addition to ERM proteins [80]. In order to migrate, the leukocyte detaches and retracts this uropod, and this process occurs under RhoA control [80]. $\mathrm{PrP}^{\mathrm{C}}$ silencing alters RhoA activation and reduces ERM phosphorylation with consequent inhibition of uropod formation, since ERM protein activation is essential for this process [74]. As a result, $\mathrm{PrP}^{\mathrm{C}}$-deficient monocytes show increased chemotaxis and motility on $\beta 1$ integrin ligands [74].

In the CNS, there is evidence of possible interactions of $\operatorname{PrP}^{\mathrm{C}}$ with NCAM1 related to physiological cell motility and migration. $\operatorname{PrP}^{\mathrm{C}}$ and NCAM seem to bind to each other on the plasma membrane, and NCAM could be one of the transmembrane factors linking $\operatorname{PrP}^{\mathrm{C}}$ and Fyn on N2a cells, since they lack expression of caveolin-1 [81]. NCAM and the L1 cell adhesion molecule (L1-CAM) also take part in neurite outgrowth. More specifically, some members of the Ig superfamily of CAMs can activate important pathways through FGFR receptors and PTKs of the Scr family, leading to tyrosine phosphorylation and thereby assisting in growth cone guidance [82]. Moreover, it has been demonstrated that $\mathrm{PrPC}^{\mathrm{C}}$ and NCAM1 interaction leads to the recruitment of Fyn to lipid rafts and stimulates outgrowth of neurites (Figure 2). This interaction has also been observed in the mouse brain [83], N2a cells [84], and rat cerebellar granule cells [85].

Another role played by this $\mathrm{PrP}^{\mathrm{C}}-\mathrm{NCAM} 1$ interaction was revealed for epithelial-mesenchymal transition (EMT). In EMT, epithelial cells develop features of mesenchymal cells towards a migratory phenotype, thus losing cell-cell adhesion structures and polarity [86]. It has been demonstrated that NCAM1 undergoes polysialylation during EMT, and this is hindered by $\operatorname{PrP}^{\mathrm{C}}$ deficiency [87]. Moreover, this perturbation was caused by decreased transcription of the polysialyltransferase gene ST8SIA2, possibly through transcriptional regulation by $\beta$-catenin [87].

Furthermore, the redistribution of NCAM1 and recruitment to caveolae or raft-like domains is an early step of EMT during gastrulation of human embryonic stem cells. This occurs concomitantly with stimulation of p59Fyn (from the Src family kinase), activation of FAK, and the association of integrin-mediated FA [88]. In $\mathrm{PrP}^{\mathrm{C}}$-1-deficient zebrafish embryos, blastodermal margin cells showed slower migration, while $\mathrm{PrP}^{\mathrm{C}}$-1-deficient blastomeres showed impaired ability to re-establish cellular contacts. PrPC -1 in normal zebrafish embryos, however, increased p59Fyn at cell contacts, in addition to modulating E-cadherin through regulation of its dynamics from intracellular stores to the plasma membrane. It is noteworthy that this altered phenotype of $\operatorname{PrP}^{\mathrm{C}}$-1-deficient zebrafish embryos was rescued with the introduction of mammalian $\operatorname{PrP}^{\mathrm{C}}$ [34]. 
Moreover, expression of $\mathrm{PrP}^{\mathrm{C}}$ and NCAM1 increases substantially during early EMT induction in mice. In the same model, $\mathrm{PrP}^{\mathrm{C}}$ increased NCAM1 polysialysation during EMT via modulation of ST8SIA2 transcription [87].

Thus, the physiological roles of $\operatorname{PrP}^{\mathrm{C}}$ in cell migration seem to occur through direct binding to its targets or via indirect activation of signaling kinases. Hitherto, the main players described in $\mathrm{PrP}^{\mathrm{C}}$-mediated cell adhesion are those related to Src kinases and adhesion proteins in the plasma membrane, and $\beta$-catenin in the cytosol and nucleus, regulating gene expression. Finding novel $\operatorname{PrP}^{\mathrm{C}}$-collaborating molecules or even attributing new roles to known important partners in the modulation of cellular motility, such as STI1, can bring important information for understanding this process, not only in the physiological context, but especially the contribution of $\operatorname{PrP}^{\mathrm{C}}$ in pathological processes such as tumor cell migration, which are addressed in the following section.

\section{Cellular Prion Protein in Cancer Cell Motility}

Cell motility mechanisms are quite relevant for cancer survival and are orchestrated by a variety of molecules, including prion protein. The processes of invasion and metastasis allow cancer cells to spread throughout tissues [89], which hinders surgical resections and therapy [90-92]. These malignant behaviors are associated with poor prognoses and higher recurrence rates of several cancer types, such as colorectal adenocarcinoma [93], glioblastoma [94], metastatic gastric cancer [95], and melanoma [96]. Strikingly, metastases have been linked to approximately $90 \%$ of cancer-related deaths [89]. Tumor resection is a common approach in cancer treatment [97-100], although data from the literature demonstrate that attempting to resect a tumor may contribute to recurrence and to the cancer capability of forming metastases [101,102]. Concerning these issues, many studies have been focusing on understanding the motility mechanisms of cancer cells and molecules that may be involved in these processes.

Cancer cells can migrate and invade adjacent tissues, and the expression and secretion of proteins related to cell-cell adhesion and ECM degradation are crucial to the invasion and metastasis development during malignant cancers [103]. Invasion occurs when cells penetrate the surrounding tissue, or stroma, through the extracellular matrix and cell-cell interactions [103]. Once these cells cross the basement membranes, they can progress to intravasation of vessels, into the vascular or lymphatic circulation, characterizing the beginning of metastasis. In the next step, the extravasation into the lumen of the vessels of the circulatory system lead cancer cells to establish new tumors (micrometastasis) in any other tissue or organ in the body, generating new secondary and tertiary tumors (colonization) [104].

Mechanisms of invasion and metastasis are closely related and use similar strategies of protein interactions and secretion of proteases, both being considered as a unique hallmark of cancer [105]. These proteins include CAMs such as those from the cadherin and integrin families, which are responsible for ECM interactions [105]. For example, E-cadherin can modulate cell-cell interaction through $\beta$-catenin modulation and, in many cancers, the loss of E-cadherin expression promotes invasion and metastasis, which can be associated with EMT processes [104,106-108]. On the other hand, N-cadherin expression is increased in several tumors [104,109]. NCAM is another example of a molecule whose expression is related to invasion and metastasis of some types of neoplasms [105,110]. Furthermore, there are many subtypes of integrins expressed in several cancer cells, especially in carcinomas. They can shift the types of integrins expressed on the cell surface according to the ECM, thus facilitating migration and, consequently, invasion and metastasis $[105,111]$. Additionally, with adhesion molecules, expression of extracellular proteases is crucial to degrade components in ECM to facilitate motility, which can be expressed not only by cancer cells, but also by stroma and inflammatory cells present in the surrounding tissue [105,112]. Indeed, this crosstalk between tumor cells and stroma is extremely important for tumor invasion-metastasis cascades. For example, mesenchymal stem cells can secrete factors that increase invasion and macrophages can 
secrete matrix-degrading proteases as metalloproteinases, facilitating the intravasation to circulatory vessels [104,113-115].

Briefly, the tumor microenvironment is rich in cell-cell and cell-ECM interactions, leading to a close relationship between components in these niches. As such, they work together to facilitate cell migration, promoting invasion and metastatic processes and, consequently, cancer progression.

$\mathrm{PrP}^{\mathrm{C}}$ has been implicated in the cell motility of several cancer types, including colon and colorectal cancer. Some cells within colorectal carcinoma express $\operatorname{PrP}^{\mathrm{C}}$ and are spread across the parenchyma of the tumor, albeit they are concentrated mainly in the invasive front of cancer [116], which, in this case, is the region where the majority of EMT occurs [116]. Consistently, it has been shown that $\operatorname{PrP}^{\mathrm{C}}$ induces EMT in colon adenocarcinoma and colorectal carcinoma cell lines, modulating protein expression levels of E-cadherin and $\mathrm{N}$-cadherin as well as the translocation of $\beta$-catenin [116]. Moreover, $\operatorname{PrPC}$ is also involved in the metastatic potential of these cells, because it triggers the Fyn-SP1-SATB1 pathway to promote metastasis [116]. Remarkably, the normal tissue that surrounds colorectal carcinoma shows low $\operatorname{PrP}^{\mathrm{C}}$ expression compared with the cancerous tissue [116]. Additionally, in colorectal adenocarcinoma cell lines, $\operatorname{PrP}^{\mathrm{C}}$ interaction with STI1 was related to cell migration and invasion by activating ERK1/2 signaling [93]. Data from the literature have demonstrated that some colorectal cancer lineages exhibit a subpopulation of cancer stem cells that express $\operatorname{PrP}^{C}$ and are positive for the stem cell marker CD44 [117]. In these cancer stem cells, the transcription factor Twist acts downstream of $\mathrm{PrP}^{\mathrm{C}}$ and mediates EMT [117]. Furthermore, it has been demonstrated that $\mathrm{PrP}^{\mathrm{C}}$ interacts with the ECM protein laminin, leading to activation of the MAPK cascade and induction of EMT [117]. In $\mathrm{PrP}^{\mathrm{C}}$-overexpressing colon cancer cell lines, it was observed that this protein is involved in cell adhesion to fibronectin and collagen in the ECM [118]. Moreover, $\operatorname{PrP}^{\mathrm{C}}$ augments both the growth and the motility of these cancer cells [118].

Besides colon and colorectal cancer, $\mathrm{PrP}^{\mathrm{C}}$ also plays important roles in the motility of pancreatic cancer cells. Normal pancreatic tissues do not express $\mathrm{PrP}^{\mathrm{C}}$, whereas pancreatic ductal adenocarcinoma (PDAC) cell lines express an alternative form of $\mathrm{PrP}^{\mathrm{C}}$ - the so-called pro-PrPC, which retains a GPI-anchor peptide signal sequence that crosses the plasma membrane [119-121]. In these PDAC cell lineages, this modification enables $\mathrm{PrPC}^{\mathrm{C}}$ to interact with certain molecules such as filamin A (FLNa) [119-121] and Notch1 [119], forming multiprotein complexes on the cellular membranes [119]. The interaction between $\mathrm{PrP}^{\mathrm{C}}$ and Notch1 upregulates the latter, stimulating cell growth and invasion [119]. Importantly, $\mathrm{PrP}^{\mathrm{C}}$ expression is directly associated with the invasive capacity of this pancreatic cancer [121]. Yet, the interactivity between $\mathrm{PrPC}^{\mathrm{C}}$ and FLNa has implications on the motility of PDAC cell lines [120].

In melanoma, $\mathrm{PrP}^{\mathrm{C}}$ also exists in the pro- $\mathrm{PrP}^{\mathrm{C}}$ form, and in FLNa deficient melanoma cell lines, modulations in the PRNP gene expression affect cell migration [122]. In addition, $\mathrm{PrP}^{\mathrm{C}}$ modulates actin polymerization through Akt and HSP27 [122].

$\operatorname{PrP}^{\mathrm{C}}$ has also been associated with the invasive and metastatic processes of gastric cancer. $\operatorname{PrP}^{\mathrm{C}}$ is highly expressed in metastatic gastric cancer and it has been observed that this protein contributes to the adhesive capability of gastric cancer cell lines [123]. In addition, it has also been shown that $\mathrm{PrP}^{\mathrm{C}}$ plays a role in gastric cancer invasion through the ERK1/2 pathway $[29,123]$, as well as in MMP11 expression at both mRNA and protein levels [123]. Concerning the ability of the gastric tumor to metastasize, $\operatorname{PrP}^{C}$ is related to gastric cancer metastasis to the liver [123] and lymph nodes [124].

Regarding lung cancer, the PRNP gene is upregulated by NFIL3 in invasive lung adenocarcinoma (ILA) cell lines [90] and, at the protein level, $\mathrm{PrP}^{\mathrm{C}}$ expression is widely observed in invasive tumors, but not in in situ tumors [90]. Furthermore, lamellipodia regions of ILA cell lines show augmented $\operatorname{PrPC}$ expression, and this protein modulates the levels of active Rac1 and the migration of these cells [90]. $\mathrm{PrP}^{\mathrm{C}}$ has been implicated in the metastatic capability of ILA in in vivo assays, and $\mathrm{PrP}^{\mathrm{C}}$ interaction with the JNK pathway induces the motility of ILA cell lines [90]. In addition, NFIL3 and $\operatorname{PrP}^{C}$ act towards cancer cell migration [90].

In breast cancer cell lines, $\mathrm{PrP}^{\mathrm{C}}$-overexpressing cells demonstrated an intensified ability to migrate and invade, without alterations in cancer cell proliferation [124]. Furthermore, it has been shown that 
a higher expression of $\mathrm{PrP}^{\mathrm{C}}$ upregulates MMP9 at mRNA levels and, consequently, protein levels, by triggering the NF- $\mathrm{KB}$ and ERK pathways, which may contribute to the motility of this cancer [124]. Moreover, multidrug-resistant breast cancer cell lines show increased $\mathrm{PrP}^{\mathrm{C}}$ and $\mathrm{CD} 44$ expressions and interactivity between them, with the latter modulating $\operatorname{PrP}^{\mathrm{C}}$ [125]. In addition, the interaction held by these two proteins is involved in cell migration mechanisms through the EGFR, CD147, MMP2 and MMP9 proteins, which act as downstream effectors [125].

Among gliomas, glioblastoma multiforme (GBM) is a highly invasive and aggressive tumor [94] that presents $\operatorname{PrP}^{\mathrm{C}}$ upregulation [33]. It has been demonstrated that $\operatorname{PrP}^{\mathrm{C}}$ may be involved in the recruitment of E-cadherin to the plasma membrane of GBM stem cells (GSCs) and, in addition, $\operatorname{PrP}^{\mathrm{C}}$ was shown to influence the localization of $\beta$-catenin [31]. Additionally, $\operatorname{PrP}^{\mathrm{C}}$ was associated with the adhesion and mobility of GSCs, given that changes in $\mathrm{PrP}^{\mathrm{C}}$ expression affect the migration of these cells on laminin as well as the expression of integrin $\alpha 6$ [31].

In neuroblastoma cell lines, expression of $\operatorname{PrP}^{\mathrm{C}}$ is involved in cell aggregation and $\operatorname{PrP}^{\mathrm{C}}$-mediated cell adhesion does not depend on cations [126].

Interestingly, whereas some non-neoplastic tissues present low $\operatorname{PrP}^{\mathrm{C}}$ expression, this protein is upregulated in cancer tissue samples $[116,119]$. Moreover, $\operatorname{PrP}^{\mathrm{C}}$ also shows higher expression in invasive and metastatic cancers compared with non-invasive and non-metastatic ones $[90,123]$.

In summary, these data support an important role for $\operatorname{PrP}^{\mathrm{C}}$ in cell motility processes of several cancer types, since $\operatorname{PrP}^{\mathrm{C}}$ has been widely shown to be related to cancer cell migration, invasion and metastasis, being involved in the recruitment of molecules and signaling platforms, in the modulation of the expression of genes and proteins, and in the activation of intracellular pathways in tumor cells (Table 1). Finally, these data point to $\operatorname{PrP}^{C}$ as a potential target for cancer treatments, given that its targeting may reduce the malignant behavior of several tumors.

Table 1. List of tumors along with respective $\mathrm{PrP}^{\mathrm{C}}$ functions associated with the modulation of invasion and metastasis process.

\begin{tabular}{|c|c|}
\hline Types of tumor & $\mathrm{PrPC}^{\mathrm{C}}$ function in tumor cell motility \\
\hline \multirow{4}{*}{ Colorectal } & $\mathrm{PrPC}^{\mathrm{C}}$ interacts with STI-1 to activate ERK1/2 and modulate migration and invasion [93] \\
\hline & $\operatorname{PrP}^{\mathrm{C}}$ interacts with laminin to activate MAPK pathway and induce EMT [117] \\
\hline & $\begin{array}{l}\mathrm{PrP}^{\mathrm{C}} \text { modulates E-cadherin and } \mathrm{N} \text {-cadherin, as well as translocation of } \beta \text {-catenin to induce EMT } \\
{[116]}\end{array}$ \\
\hline & $\mathrm{PrP}^{\mathrm{C}}$ has metastatic potential by triggering Fyn-SP1-SATB1 pathway [116] \\
\hline \multirow{3}{*}{ Colon } & $\operatorname{PrPC}^{\mathrm{C}}$ is involved in the cell adhesion to fibronectin and collagen to the ECM [118] \\
\hline & $\begin{array}{c}\mathrm{PrP}^{\mathrm{C}} \text { modulates E-cadherin and } \mathrm{N} \text {-cadherin, as well as translocation of } \beta \text {-catenin to the nucleus, } \\
\text { inducing EMT [116] }\end{array}$ \\
\hline & $\mathrm{PrP}^{\mathrm{C}}$ has metastatic potential by triggering Fyn-SP1-SATB1 pathway [116] \\
\hline \multirow{3}{*}{ Pancreatic ductal adenocarcinoma } & Pro-PrPC retains a GPI-anchor peptide signal sequence that crosses the plasma membrane [119-121] \\
\hline & Pro-PrPC interacts with Notch1 stimulating cell growth and invasion [119] \\
\hline & Pro-PrPC interacts with FLNa affecting cell motility [119-121] \\
\hline \multirow{3}{*}{ Melanoma } & Pro-PrPC retains a GPI-anchor peptide signal sequence that crosses the plasma membrane [122] \\
\hline & In FLNa deficient cells, $P R N P$ expression affects cell migration [122] \\
\hline & $\mathrm{PrPC}^{\mathrm{C}}$ modulates actin polymerization trough AKT and HSP27 [122] \\
\hline \multirow{2}{*}{ Gastric } & $\mathrm{PrPC}^{\mathrm{C}}$ contributes to cell adhesion [123] \\
\hline & Through ERK1/2, $\operatorname{PrP}^{\mathrm{C}}$ modulates invasion and mRNA and protein levels of MMP11 [123] \\
\hline \multirow{5}{*}{ Invasive lung adenocarcinoma } & $\mathrm{PrPC}^{\mathrm{C}}$ is expressed in invasive tumors, but not in in situ tumors [90] \\
\hline & Enhanced $\mathrm{PrP}^{\mathrm{C}}$ expression in lamellipodia [90] \\
\hline & PrPC modulates Rac1 expression and cell migration [90] \\
\hline & $\mathrm{PrP}^{\mathrm{C}}$ modulates JNK pathways and induces cell motility [90] \\
\hline & Together with NFIL3, PrPC acts towards cancer cell migration [90] \\
\hline \multirow{3}{*}{ Breast } & $\operatorname{PrP}^{\mathrm{C}}$ overexpression intensifies cell migration and invasiveness [124] \\
\hline & $\begin{array}{l}\text { At higher expression PrPC upregulates MMP9 protein and mRNA levels through NF-kB and ERK } \\
\text { pathways, contributing to cell motility [124] }\end{array}$ \\
\hline & $\begin{array}{l}\text { Together with CD44, } \mathrm{PrP}^{\mathrm{C}} \text { is involved in cell migration mechanisms through the proteins EGFR, } \\
\text { CD147, MMP2 and MMP9 [125] }\end{array}$ \\
\hline \multirow{3}{*}{ Glioblastoma multiforme } & $\mathrm{PrPC}^{\mathrm{C}}$ modulates recruitment of E-cadherin to the plasma membrane of GSCs [31] \\
\hline & $\mathrm{PrP}^{\mathrm{C}}$ modulates subcellular localization of $\beta$-catenin [31] \\
\hline & Changes in $\mathrm{PrP}^{\mathrm{C}}$ expression affects cell migration on laminin as well as integrin $\alpha 6$ expression [31] \\
\hline
\end{tabular}




\section{Perspectives and Conclusions}

Cell motility is an important process to the development, maintenance and healing of all tissues, and is essential for the normal functioning of the body. These processes require the transient formation of multiprotein complexes to modulate different signaling cascades which, together, lead to a close-fitting regulation of cellular and molecular phenotypes. As a scaffold protein, $\mathrm{PrP}^{\mathrm{C}}$ functions as a promiscuous molecule that is able to interact with several partners and, as discussed throughout this review, orchestrates many signaling pathways involved with cell motility. $\operatorname{This~}^{\mathrm{PrP}} \mathrm{P}^{\mathrm{C}}$ scaffolding property might favor protein recruitment and higher-order assemblies into a dynamic molecular platform on the plasma membrane and provide an efficient and reversible mechanism to control intercellular signaling pathways.

The seemingly controversial roles of $\operatorname{PrP}^{\mathrm{C}}$, such as neurite growth, axon guidance and leukocyte migration, could be explained by the dependence of $\operatorname{PrP}^{\mathrm{C}}$ on the cell context. For instance, despite the reports supporting $\mathrm{PrP}^{\mathrm{C}}$ function in neurite sprouting, a mechanism proposed in 2010 shows that, depending on the specific binding partner of $\mathrm{PrP}^{\mathrm{C}}$ on the cell membrane, it may or may not influence protrusion formation in growth cones [57]. These findings highlight even further the role of $\operatorname{PrP}^{\mathrm{C}}$ as a sensor of environmental cues, functioning as a key molecule in dynamic control of molecular platforms, in the CNS and other tissues, as well as in health and disease, to trigger different outcomes for the cell.

Although $\operatorname{PrP}^{\mathrm{C}}$ partners are mostly the same in different tissues- $\beta 1$-integrin and Src kinases, for example - the balance between upregulated and downregulated signaling pathways will ultimately dictate the function of $\mathrm{PrP}^{\mathrm{C}}$ in the cell at a given context. In several processes described in this review, however, there are still gaps of knowledge and unknown binding partners of $\operatorname{PrP}^{\mathrm{C}}$ to explain its effects on cell motility. Thus, the characterization of novel ligands assigned to signaling propagation of $\mathrm{PrP}^{\mathrm{C}}$ scaffolding platform is of utmost importance to understand $\mathrm{PrP}^{\mathrm{C}}$ physiological role during cell movement.

In addition, $\mathrm{PrP}^{\mathrm{C}}$ can also be co-opted by tumoral cells to ensure their survival. Through cell motility processes, tumor cells are capable of invading and metastasizing to other organs and, although the exact percentage is still a debate, a recent study concluded that metastasis could be responsible for more than $65 \%$ of cancer deaths [127], while others claim it could be as high as $90 \%$ [89]. $\operatorname{PrP}^{\mathrm{C}}$ expression is upregulated in several types of invasive and metastatic cancers $[90,123]$. Thus, an intriguing parallel can be established between $\mathrm{PrP}^{\mathrm{C}}$ physiological and cancer-related functions. While preferential localization of $\mathrm{PrPC}^{\mathrm{C}}$ in specific membrane microdomains favors its interaction with Fyn, supporting proper axon guidance [51], actin cytoskeleton reorganization [37], and $\mathrm{N}$-cadherin transport in the plasma membrane [53], $\mathrm{PrP}^{\mathrm{C}}$ is also involved in the promotion of metastasis through Fyn activation [116]. Additionally, F-actin and $\mathrm{PrP}^{\mathrm{C}}$ bind STI1 through the same domain [62], and several lines of evidence point to the promotion of neuroprotection through $\mathrm{PrP}^{\mathrm{C}}-\mathrm{STI} 1$ interaction [59-61], while the same interaction was associated to cancer cell migration and invasion through ERK1/2 activation [93]. These are some of the examples of physiological $\operatorname{PrP}^{\mathrm{C}}$-binding preferences that cancer cells might hijack to improve tumor maintenance, invasion and migration.

Furthermore, as discussed in this review, cancer cells appear to take advantage of the $\mathrm{PrP}^{\mathrm{C}}$ role in cell motility through its binding to N-cadherin and E-cadherin to promote EMT and increase tumor invasion and aggressiveness. In the context of increased survival and proliferation seen in cancer cells, the $\mathrm{PrP}^{\mathrm{C}}$ function in cell motility seems to be enhanced. Moreover, with the $\mathrm{PrP}^{\mathrm{C}}$ scaffolding properties facilitating cell signaling, cancer cells are able to invade and spread. Given the functional plasticity of $\mathrm{PrP}^{\mathrm{C}}$ and its scaffold feature, a deep understanding of its role in the organization and activity of higher-order molecular modules on the cell membrane, in the context of space and time, is imperative to unveil its function as a signaling organizer. Finally, these data demonstrate the importance of uncovering $\mathrm{PrP}^{\mathrm{C}}$ partners and unveiling their role in motility-related processes, as well as the impact of this molecule as a target for the development of new and effective therapies against metastatic cancer. 
Author Contributions: Review conceptualization M.B.P. and M.H.L.; writing M.B.P., M.I.M.E., R.N.A., B.P.C., C.F.d.L.F., J.M.B. and R.P.I.; reviewing and editing M.B.P., M.I.M.E., R.N.A., B.P.C., C.F.d.L.F., J.M.B., R.P.I. and M.H.L.; figure conceptualization M.B.P. and B.P.C.; figure design M.I.M.E.; table conceptualization and design M.B.P. All authors have read and agreed to the published version of the manuscript.

Funding: This study was supported by Fundação de Amparo à Pesquisa do Estado de São Paulo (FAPESP, Processes numbers: M.B.P.: 2017/26158-0; M.I.M.E.: 2019/11097-1; R.N.A.: 2020/04687-4; B.P.C.: 2019/14952-0; C.F.d.L.F.: 2019/14741-9; J.M.B.: 2020/07450-5; R.P.I.: 2019/12710-9; M.H.L.: 2018/15557-4;) and Conselho Nacional de Desenvolvimento Científico e Tecnológico (CNPq, Process number: J.M.B.: 101796/2020-0).

Conflicts of Interest: The authors declare no conflict of interest.

\section{References}

1. Hohmann, T.; Dehghani, F. The Cytoskeleton-A Complex Interacting Meshwork. Cells 2019, 8, 362. [CrossRef] [PubMed]

2. Aman, A.; Piotrowski, T. Cell migration during morphogenesis. Dev. Biol. 2010, 341, 20-33. [CrossRef] [PubMed]

3. Lamalice, L.; Le Boeuf, F.; Huot, J. Endothelial cell migration during angiogenesis. Circ. Res. 2007, 100, 782-794. [CrossRef] [PubMed]

4. Gerthoffer, W.T. Mechanisms of vascular smooth muscle cell migration. Circ. Res. 2007, 100, 607-621. [CrossRef]

5. Cramer, L.P.; Mitchison, T.J.; Theriot, J.A. Actin-dependent motile forces and cell motility. Curr. Opin. Cell Biol. 1994, 6, 82-86. [CrossRef]

6. Krawczyk, W.S. A pattern of epidermal cell migration during wound healing. J. Cell Biol. 1971, 49, $247-263$. [CrossRef]

7. Ananthakrishnan, R.; Ehrlicher, A. The Forces Behind Cell Movement. Int. J. Biol. Sci. 2007, 3, 303-317. [CrossRef]

8. Stricker, J.; Falzone, T.; Gardel, M.L. Mechanics of the F-actin cytoskeleton. J. Biomech. 2010, 43, 9-14. [CrossRef]

9. Nelson, W.J. Adaptation of core mechanisms to generate cell polarity. Nature 2003, 422, 766-774. [CrossRef]

10. Trepat, X.; Chen, Z.; Jacobson, K. Cell migration. Compr. Physiol. 2012, 2, 2369-2392.

11. Carnell, M.J.; Insall, R.H. Actin on disease - Studying the pathobiology of cell motility using Dictyostelium discoideum. Semin. Cell Dev. Biol. 2011, 22, 82-88. [CrossRef] [PubMed]

12. Thiery, J.P.; Acloque, H.; Huang, R.Y.J.; Nieto, M.A. Epithelial-Mesenchymal Transitions in Development and Disease. Cell 2009, 139, 871-890. [CrossRef] [PubMed]

13. Manson, J.; West, J.D.; Thomson, V.; McBride, P.; Kaufman, M.H.; Hope, J. The prion protein gene: A role in mouse embryogenesis? Development 1992, 115, 117-122. [PubMed]

14. Lopes, M.H.; Santos, T.G. Prion potency in stem cells biology. Prion 2012, 6, 142-146. [CrossRef] [PubMed]

15. Hartmann, C.A.; Martins, V.R.; Lima, F.R.S. High levels of Cellular Prion Protein improve astrocyte development. FEBS Lett. 2013, 587, 238-244. [CrossRef] [PubMed]

16. Bribián, A.; Fontana, X.; Llorens, F.; Gavín, R.; Reina, M.; García-Verdugo, J.M.; Torres, J.M.; de Castro, F.; del Río, J.A. Role of the cellular prion protein in oligodendrocyte precursor cell proliferation and differentiation in the developing and adult mouse CNS. PLOS ONE 2012, 7.

17. Adle-Biassette, H.; Verney, C.; Peoc'h, K.; Dauge, M.C.; Razavi, F.; Choudat, L.; Gressens, P.; Budka, H.; Henin, D. Immunohistochemical expression of prion protein (PrPC) in the human forebrain during development. J. Neuropathol. Exp. Neurol. 2006, 65, 698-706. [CrossRef]

18. Glatzel, M.; Aguzzi, A. $\operatorname{PrP}(\mathrm{C})$ expression in the peripheral nervous system is a determinant of prion neuroinvasion. J. Gen. Virol. 2000, 81, 2813-2821. [CrossRef]

19. Peralta, O.A.; Eyestone, W.H. Quantitative and qualitative analysis of cellular prion protein (PrP C) expression in bovine somatic tissues. Prion 2009, 3, 161-170. [CrossRef]

20. Stahl, N.; Baldwin, M.A.; Hecker, R.; Pan, K.M.; Burlingame, A.L.; Prusiner, S.B. Glycosylinositol Phospholipid Anchors of the Scrapie and Cellular Prion Proteins Contain Sialic Acid. Biochemistry 1992, 31, 5043-5053. [CrossRef]

21. Riek, R.; Hornemann, S.; Wider, G.; Billeter, M.; Glockshuber, R.; Wüthrich, K. NMR structure of the mouse prion protein domain $\mathrm{PrP}(121-231)$. Nature 1994. [CrossRef] [PubMed] 
22. Haire, L.F.; Whyte, S.M.; Vasisht, N.; Gill, A.C.; Verma, C.; Dodson, E.J.; Dodson, G.G.; Bayley, P.M. The Crystal Structure of the Globular Domain of Sheep Prion Protein. J. Mol. Biol. 2004, 336, 1175-1183. [CrossRef] [PubMed]

23. Taubner, L.M.; Bienkiewicz, E.A.; Copié, V.; Caughey, B. Structure of the flexible amino-terminal domain of prion protein bound to a sulfated glycan. J. Mol. Biol. 2010, 395, 475-490. [CrossRef] [PubMed]

24. Smith, C.J.; Drake, A.F.; Banfield, B.A.; Bloomberg, G.B.; Palmer, M.S.; Clarke, A.R.; Collinge, J. Conformational properties of the prion octa-repeat and hydrophobic sequences. FEBS Lett. 1997, 405, 378-384. [CrossRef]

25. Slapšak, U.; Salzano, G.; Amin, L.; Abskharon, R.N.N.; Ilc, G.; Zupančič, B.; Biljan, I.; Plavec, J.; Giachin, G.; Legname, $\mathrm{G}$. The $\mathrm{N}$ terminus of the prion protein mediates functional interactions with the neuronal cell adhesion molecule (NCAM) fibronectin domain. J. Biol. Chem. 2016, 291, 21857-21868. [CrossRef]

26. Ulbrich, S.; Janning, P.; Seidel, R.; Matschke, J.; Gonsberg, A.; Jung, S.; Glatzel, M.; Engelhard, M.; Winklhofer, K.F.; Tatzelt, J. Alterations in the brain interactome of the intrinsically disordered N-terminal domain of the cellular prion protein (PrPC) in Alzheimer's disease. PLoS ONE 2018, 13, 1-15. [CrossRef]

27. Didonna, A. Prion protein and its role in signal transduction. Cell. Mol. Biol. Lett. 2013, 18, $209-230$. [CrossRef]

28. Martellucci, S.; Santacroce, C.; Santilli, F.; Manganelli, V.; Sorice, M.; Mattei, V. Prion protein in stem cells: A lipid raft component involved in the cellular differentiation process. Int. J. Mol. Sci. 2020, 21, 4168. [CrossRef]

29. Santos, T.G.; Lopes, M.H.; Martins, V.R. Targeting prion protein interactions in cancer. Prion 2015, 9, 165-173. [CrossRef]

30. Martins, V.R.; Beraldo, F.H.; Hajj, G.N.; Lopes, M.H.; Lee, K.S.; Prado, M.A.; Linden, R. Prion protein: Orchestrating neurotrophic activities. Curr. Issues Mol. Biol. 2010, 12, 63-86.

31. Iglesia, R.P.; Prado, M.B.; Cruz, L.; Martins, V.R.; Santos, T.G.; Lopes, M.H. Engagement of cellular prion protein with the co-chaperone Hsp70/90 organizing protein regulates the proliferation of glioblastoma stem-like cells. Stem Cell Res. Ther. 2017, 8, 1-14. [CrossRef] [PubMed]

32. Santos, T.G.; Silva, I.R.; Costa-Silva, B.; Lepique, A.P.; Martins, V.R.; Lopes, M.H. Enhanced neural progenitor/stem cells self-renewal via the interaction of stress-inducible protein 1 with the prion protein. Stem Cells 2011, 29, 1126-1136. [CrossRef] [PubMed]

33. Lopes, M.H.; Santos, T.G.; Rodrigues, B.R.; Queiroz-Hazarbassanov, N.; Cunha, I.W.; Wasilewska-Sampaio, A.P.; Costa-Silva, B.; Marchi, F.A.; Bleggi-Torres, L.F.; Sanematsu, P.I.; et al. Disruption of prion protein-HOP engagement impairs glioblastoma growth and cognitive decline and improves overall survival. Oncogene 2015, 34, 3305-3314. [CrossRef] [PubMed]

34. Málaga-Trillo, E.; Solis, G.P.; Schrock, Y.; Geiss, C.; Luncz, L.; Thomanetz, V.; Stuermer, C.A.O. Regulation of Embryonic Cell Adhesion by the Prion Protein. PLoS ONE 2009, 7, 576-590.

35. Viegas, P.; Chaverot, N.; Enslen, H.; Perrière, N.; Couraud, P.O.; Cazaubon, S. Junctional expression of the prion protein PrPC by brain endothelial cells: A role in trans-endothelial migration of human monocytes. J. Cell Sci. 2006, 119, 4634-4643. [CrossRef]

36. Morel, E.; Fouquet, S.; Chateau, D.; Yvernault, L.; Frobert, Y.; Pinçon-Raymond, M.; Chambaz, J.; Pillot, T.; Rousset, M. The Cellular Prion Protein PrPc Is Expressed in Human Enterocytes in Cell-Cell Junctional Domains. J. Biol. Chem. 2004, 279, 1499-1505. [CrossRef]

37. Stuermer, C.A.O.; Langhorst, M.F.; Wiechers, M.F.; Legler, D.F.; von Hanwehr, S.H.; Guse, A.H.; Plattner, H. PrPC capping in T cells promotes its association with the lipid raft proteins reggie- 1 and reggie-2 and leads to signal transduction. FASEB J. 2004, 18, 1731-1733. [CrossRef]

38. Bremer, J.; Baumann, F.; Tiberi, C.; Wessig, C.; Fischer, H.; Schwarz, P.; Steele, A.D.; Toyka, K.V.; Nave, K.A.; Weis, J.; et al. Axonal prion protein is required for peripheral myelin maintenance. Nat. Neurosci. 2010, 13, 310-318. [CrossRef]

39. Nuvolone, M.; Hermann, M.; Sorce, S.; Russo, G.; Tiberi, C.; Schwarz, P.; Minikel, E.; Sanoudou, D.; Pelczar, P.; Aguzzi, A. Strictly co-isogenic C57BL/6J-Prnp-/- mice: A rigorous resource for prion science. J. Exp. Med. 2016, 213, 313-327. [CrossRef]

40. Tanaka, A.; Fujii, Y.; Kasai, N.; Okajima, T.; Nakashima, H. Regulation of neuritogenesis in hippocampal neurons using stiffness of extracellular microenvironment. PLoS ONE 2018, 13, 1-16. [CrossRef] 
41. Wulf, M.A.; Senatore, A.; Aguzzi, A. The biological function of the cellular prion protein: An update. BMC Biol. 2017, 15, 1-13. [CrossRef] [PubMed]

42. Lee, J.; Song, K.H.; Kim, T.; Doh, J. Endothelial cell focal adhesion regulates transendothelial migration and subendothelial crawling of T cells. Front. Immunol. 2018, 9, 1-9. [CrossRef] [PubMed]

43. Loubet, D.; Dakowski, C.; Pietri, M.; Pradines, E.; Bernard, S.; Callebert, J.; Ardila-Osorio, H.; Mouillet-Richard, S.; Launay, J.; Kellermann, O.; et al. Neuritogenesis: The prion protein controls $\beta 1$ integrin signaling activity. FASEB J. 2012, 26, 678-690. [CrossRef] [PubMed]

44. Huveneers, S.; Danen, E.H.J. Adhesion signaling - Crosstalk between integrins, Src and Rho. J. Cell Sci. 2009, 122, 1059-1069. [CrossRef] [PubMed]

45. Katoh, K. Activation of Rho-kinase and focal adhesion kinase regulates the organization of stress fibers and focal adhesions in the central part of fibroblasts. PeerJ 2017, 2017. [CrossRef] [PubMed]

46. Meldolesi, J. Neurite outgrowth: This process, first discovered by Santiago Ramon y Cajal, is sustained by the exocytosis of two distinct types of vesicles. Brain Res. Rev. 2011, 66, 246-255. [CrossRef]

47. Kahn, O.I.; Baas, P.W. Microtubules and Growth Cones: Motors Drive the Turn. Trends Neurosci. 2016, 176, 100-106. [CrossRef]

48. Omotade, O.F.; Pollitt, S.L.; Zheng, J.Q. Actin-based growth cone motility and guidance. Mol. Cell. Neurosci. 2017, 84, 4-10. [CrossRef]

49. Kohtaro, M.; Emmerling, K.; Manuelidis, L. Proliferative arrest of neural cells induces prion protein synthesis, nanotube formation and cell-to-cell contacts. J Cell Biochem. 2014, 23, 1-7.

50. Bueler, H.; Fischer, M.; Lang, Y.; Bluethmann, H.; Lippt, H.; Dearmond, S.J.; Prusiner, S.B.; Aguet, M.; Weissmann, C. Normal development and behaviour of mice lacking the neuronal cell-surface PrP protein. Nature 1992, 356, 577-582. [CrossRef]

51. Bodrikov, V.; Solis, G.P.; Stuermer, C.A.O. Prion protein promotes growth cone development through reggie/flotillin-dependent N-cadherin trafficking. J. Neurosci. 2011, 31, 18013-18025. [CrossRef] [PubMed]

52. Solis, G.P.; Malaga-Trillo, E.; Plattner, H.; Stuermer, C.A.O. Cellular roles of the prion protein in association with reggie/flotillin microdomains. Front. Biosci. 2010, 15, 1075-1085. [CrossRef] [PubMed]

53. Stuermer, C.A.O. How reggies regulate regeneration and axon growth. Cell Tissue Res. 2012, 349, 71-77. [CrossRef] [PubMed]

54. Gomez, T.M.; Robles, E.; Poo, M.M.; Spitzer, N.C. Filopodial calcium transients promote substrate-dependent growth cone turning. Science (80-. ). 2001, 291, 1983-1987. [CrossRef] [PubMed]

55. Amin, L.; Nguyen, X.T.A.; Rolle, I.G.; D’Este, E.; Giachin, G.; Tran, T.H.; Šerbec, V.Č.; Cojoc, D.; Legname, G. Characterization of prion protein function by focal neurite stimulation. J. Cell Sci. 2016, 129, 3878-3891. [CrossRef] [PubMed]

56. Nguyen, X.T.A.; Tran, T.H.; Cojoc, D.; Legname, G. Copper Binding Regulates Cellular Prion Protein Function. Mol. Neurobiol. 2019, 56, 6121-6133. [CrossRef] [PubMed]

57. Devanathan, V.; Jakovcevski, I.; Santuccione, A.; Li, S.; Lee, H.J.; Peles, E.; Leshchyns'ka, I.; Sytnyk, V.; Schachner, M. Cellular form of prion protein inhibits reelin-mediated shedding of Caspr from the neuronal cell surface to potentiate Caspr-mediated inhibition of neurite outgrowth. J. Neurosci. 2010, 30, 9292-9305. [CrossRef] [PubMed]

58. Zanata, S.M.; Lopes, M.H.; Mercadante, A.F.; Hajj, G.N.M.; Chiarini, L.B.; Nomizo, R.; Freitas, A.R.O.; Cabral, A.L.B.; Lee, K.S.; Juliano, M.A.; et al. Stress-inducible protein 1 is a cell surface ligand for cellular prion that triggers neuroprotection. Embo J. 2002, 21, 3307-3316. [CrossRef]

59. Lopes, M.H.; Hajj, G.N.M.; Muras, A.G.; Mancini, G.L.; Castro, R.M.P.S.; Ribeiro, K.C.B.; Brentani, R.R.; Linden, R.; Martins, V.R. Interaction of cellular prion and stress-inducible protein 1 promotes neuritogenesis and neuroprotection by distinct signaling pathways. J. Neurosci. 2005, 25, 11330-11339. [CrossRef]

60. Beraldo, F.H.; Ostapchenko, V.G.; Xu, J.Z.; Di Guglielmo, G.M.; Fan, J.; Nicholls, P.J.; Caron, M.G.; Prado, V.F.; Prado, M.A.M. Mechanisms of neuroprotection against ischemic insult by stress-inducible phosphoprotein-1/prion protein complex. J. Neurochem. 2018, 145, 68-79. [CrossRef]

61. Landemberger, M.C.; de Oliveira, G.P.; Machado, C.F.; Gollob, K.J.; Martins, V.R. Loss of STI1-mediated neuronal survival and differentiation in disease-associated mutations of prion protein. J. Neurochem. 2018, 145, 409-416. [CrossRef] [PubMed] 
62. Beckley, S.J.; Hunter, M.C.; Kituyi, S.N.; Wingate, I.; Chakraborty, A.; Schwarz, K.; Makhubu, M.P.; Rousseau, R.P.; Ruck, D.K.; de la Mare, J.A.; et al. STIP1/HOP regulates the actin cytoskeleton through interactions with actin and changes in actin-binding proteins cofilin and profilin. Int. J. Mol. Sci. 2020, 21,3152. [CrossRef] [PubMed]

63. Song, K.; Han, H.J.; Kim, S.; Kwon, J. Thymosin beta 4 attenuates PrP(106-126)-induced human brain endothelial cells dysfunction. Eur. J. Pharmacol. 2020, 869, 172891. [CrossRef] [PubMed]

64. Schrock, Y.; Solis, G.P.; Stuermer, C.A.O. Regulation of focal adhesion formation and filopodia extension by the cellular prion protein (PrPC). FEBS Lett. 2009, 583, 389-393. [CrossRef] [PubMed]

65. Morel, E.; Fouquet, S.; Strup-Perrot, C.; Thievend, C.P.; Petit, C.; Loew, D.; Faussat, A.M.; Yvernault, L.; Pinçon-Raymond, M.; Chambaz, J.; et al. The cellular prion protein PrPc is involved in the proliferation of epithelial cells and in the distribution of junction-associated proteins. PLOS ONE 2008, 3. [CrossRef]

66. Rivera-Milla, E.; Oidtmann, B.; Panagiotidis, C.H.; Baier, M.; Sklaviadis, T.; Hoffmann, R.; Zhou, Y.; Solis, G.P.; Stuermer, C.A.O.; Málaga-Trillo, E. Disparate evolution of prion protein domains and the distinct origin of Doppel- and prion-related loci revealed by fish-to-mammal comparisons. FASEB J. 2006, 20, 317-319. [CrossRef]

67. Huc-Brandt, S.; Hieu, N.; Imberdis, T.; Cubedo, N.; Silhol, M.; Leighton, P.L.A.; Domaschke, T.; Allison, W.T.; Perrier, V.; Rossel, M. Zebrafish prion protein PrP2 controls collective migration process during lateral line sensory system development. PLoS ONE 2014, 9, 1-22. [CrossRef]

68. Watanabe, T.; Yasutaka, Y.; Nishioku, T.; Kusakabe, S.; Futagami, K.; Yamauchi, A.; Kataoka, Y. Involvement of the cellular prion protein in the migration of brain microvascular endothelial cells. Neurosci. Lett. 2011, 496, 121-124. [CrossRef]

69. Mouillet-Richard, S.; Ermonval, M.; Chebassier, C.; Laplanche, J.L.; Lehmann, S.; Launay, J.M.; Kellermann, O. Signal transduction through prion protein. Science (80-. ). 2000, 289, 1925-1928. [CrossRef]

70. Megra, B.W.; Eugenin, E.A.; Berman, J.W. Inflammatory mediators reduce surface PrPc on human BMVEC resulting in decreased barrier integrity. Lab Invest. 2017, 176, 139-148. [CrossRef]

71. Petit, C.S.V.; Barreau, F.; Besnier, L.; Gandille, P.; Riveau, B.; Chateau, D.; Roy, M.; Berrebi, D.; Svrcek, M.; Cardot, P.; et al. Requirement of cellular prion protein for intestinal barrier function and mislocalization in patients with inflammatory bowel disease. Gastroenterology 2012, 143, 122-132.e15. [CrossRef] [PubMed]

72. Alon, R.; Feigelson, S.W.; Manevich, E.; Rose, D.M.; Schmitz, J.; Overby, D.R.; Winter, E.; Grabovsky, V.; Shinder, V.; Matthews, B.D.; et al. A4B1-Dependent Adhesion Strengthening Under Mechanical Strain Is Regulated By Paxillin Association With the A4-Cytoplasmic Domain. J. Cell Biol. 2005, 171, 1073-1084. [CrossRef] [PubMed]

73. Nourshargh, S.; Hordijk, P.L.; Sixt, M. Breaching multiple barriers: Leukocyte motility through venular walls and the interstitium. Nat. Rev. Mol. Cell Biol. 2010, 11, 366-378. [CrossRef] [PubMed]

74. Richardson, D.D.; Tol, S.; Valle-Encinas, E.; Pleguezuelos, C.; Bierings, R.; Geerts, D.; Fernandez-Borja, M. The prion protein inhibits monocytic cell migration by stimulating $\beta 1$ integrin adhesion and uropod formation. J. Cell Sci. 2015, 128, 3018-3029. [CrossRef]

75. Ridley, A.J. Rho GTPase signalling in cell migration. Curr. Opin. Cell Biol. 2015, 36, 103-112. [CrossRef]

76. Wioland, H.; Guichard, B.; Senju, Y.; Myram, S.; Lappalainen, P.; Jégou, A.; Romet-Lemonne, G. ADF/Cofilin Accelerates Actin Dynamics by Severing Filaments and Promoting Their Depolymerization at Both Ends. Curr. Biol. 2017, 27, 1956-1967.e7. [CrossRef]

77. Bravo-Cordero, J.J.; Magalhaes, M.A.O.; Eddy, R.J.; Hodgson, L.; Condeelis, J. Functions of cofilin in cell locomotion and invasion. Nat. Rev. Mol. Cell Biol. 2013, 14, 405-417. [CrossRef]

78. Walsh, K.P.; Kuhn, T.B.; Bamburg, J.R. Cellular prion protein: A co-receptor mediating neuronal cofilin-actin rod formation induced by b-amyloid and proinflammatory cytokines. Prion 2014, 8, 375-380. [CrossRef]

79. Terra-Granado, E.; Berbert, L.R.; De Meis, J.; Nomizo, R.; Martins, V.R.; Savino, W.; Silva-Barbosa, S.D. Is there a role for cellular prion protein in intrathymic T cell differentiation and migration? Neuroimmunomodulation 2007, 14, 213-219. [CrossRef]

80. Friedl, P.; Weigelin, B. Interstitial leukocyte migration and immune function. Nat. Immunol. 2008, 9, 960-969. [CrossRef] 
81. Schmitt-Ulms, G.; Legname, G.; Baldwin, M.A.; Ball, H.L.; Bradon, N.; Bosque, P.J.; Crossin, K.L.; Edelman, G.M.; DeArmond, S.J.; Cohen, F.E.; et al. Binding of neural cell adhesion molecules (N-CAMs) to the cellular prion protein. J. Mol. Biol. 2001, 314, 1209-1225. [CrossRef] [PubMed]

82. Suter, D.M.; Forscher, P. Transmission of growth cone traction force through apCAM-cytoskeletal linkages is regulated by Src family tyrosine kinase activity. J. Cell Biol. 2001, 155, 427-438. [CrossRef] [PubMed]

83. Schmitt-Ulms, G.; Hansen, K.; Liu, J.; Cowdrey, C.; Yang, J.; DeArmond, S.J.; Cohen, F.E.; Prusiner, S.B.; Baldwin, M.A. Time-controlled transcardiac perfusion cross-linking for the study of protein interactions in complex tissues. Nat. Biotechnol. 2004, 22, 724-731. [CrossRef] [PubMed]

84. Watts, J.C.; Huo, H.; Bai, Y.; Ehsani, S.; Won, A.H.; Shi, T.; Daude, N.; Lau, A.; Young, R.; Xu, L.; et al. Interactome analyses identify ties of prpc and its mammalian paralogs to oligomannosidic n-glycans and endoplasmic reticulum-derived chaperones. PLoS Pathog. 2009, 5. [CrossRef]

85. Farina, F.; Botto, L.; Chinello, C.; Cunati, D.; Magni, F.; Masserini, M.; Palestini, P. Characterization of prion protein-enriched domains, isolated from rat cerebellar granule cells in culture. J. Neurochem. 2009, 110, 1038-1048. [CrossRef] [PubMed]

86. Das, V.; Bhattacharya, S.; Chikkaputtaiah, C.; Hazra, S.; Pal, M. The basics of epithelial-mesenchymal transition (EMT): A study from a structure, dynamics, and functional perspective. J. Cell. Physiol. 2018, 234, 14535-14555. [CrossRef]

87. Mehrabian, M.; Brethour, D.; Wang, H.; Xi, Z.; Rogaeva, E.; Schmitt-Ulms, G. The prion protein controls polysialylation of neural cell adhesion molecule 1 during cellular morphogenesis. PLoS One 2015, 10, 1-23. [CrossRef]

88. Lehembre, F.; Yilmaz, M.; Wicki, A.; Schomber, T.; Strittmatter, K.; Ziegler, D.; Kren, A.; Went, P.; Derksen, P.W.B.; Berns, A.; et al. NCAM-induced focal adhesion assembly: A functional switch upon loss of E-cadherin. EMBO J. 2008, 27, 2603-2615. [CrossRef]

89. Lambert, A.W.; Pattabiraman, D.R.; Weinberg, R.A. Emerging biological principles of metastasis. Cell 2017, 168, 670-691. [CrossRef]

90. Lin, S.C.; Lin, C.H.; Shih, N.C.; Liu, H.L.; Wang, W.C.; Lin, K.Y.; Liu, Z.Y.; Tseng, Y.J.; Chang, H.K.; Lin, Y.C.; et al. Cellular prion protein transcriptionally regulated by NFIL3 enhances lung cancer cell lamellipodium formation and migration through JNK signaling. Oncogene 2020, 39, 385-398. [CrossRef]

91. Simillis, C.; Kalakouti, E.; Afxentiou, T.; Kontovounisios, C.; Smith, J.J.; Cunningham, D.; Adamina, M.; Tekkis, P.P. Primary Tumor Resection in Patients with Incurable Localized or Metastatic Colorectal Cancer: A Systematic Review and Meta-analysis. World J. Surg. 2019, 43, 1829-1840. [CrossRef] [PubMed]

92. Furnari, F.B.; Fenton, T.; Bachoo, R.M.; Mukasa, A.; Stommel, J.M.; Stegh, A.; Hahn, W.C.; Ligon, K.L.; Louis, D.N.; Brennan, C.; et al. Malignant astrocytic glioma: Genetics, biology, and paths to treatment. Genes Dev. 2007, 21, 2683-2710. [CrossRef] [PubMed]

93. de Lacerda, T.C.S.; Costa-Silva, B.; Giudice, F.S.; Dias, M.V.S.; de Oliveira, G.P.; Teixeira, B.L.; dos Santos, T.G.; Martins, V.R. Prion protein binding to HOP modulates the migration and invasion of colorectal cancer cells. Clin. Exp. Metastasis 2016, 33, 441-451. [CrossRef] [PubMed]

94. Hatoum, A.; Mohammed, R.; Zakieh, O. The unique invasiveness of glioblastoma and possible drug targets on extracellular matrix. Cancer Manag. Res. 2019, 11, 1843-1855. [CrossRef]

95. Tan, H.L.; Chia, C.S.; Tan, G.H.C.; Choo, S.P.; Tai, D.W.M.; Chua, C.W.L.; Ng, M.C.H.; Soo, K.C.; Teo, M.C.C. Metastatic gastric cancer: Does the site of metastasis make a difference? Asia. Pac. J. Clin. Oncol. 2018, 15, 1-8. [CrossRef]

96. Zbytek, B.; Carlson, J.A.; Granese, J.; Ross, J.; Mihm, M.; Slominski, A. Current concepts of metastasis in melanoma. Expert Rev. Dermatol. 2008, 3, 569-585. [CrossRef]

97. Reni, M.; Mazza, E.; Zanon, S.; Gatta, G.; Vecht, C.J. Central nervous system gliomas. Crit. Rev. Oncol. Hematol. 2017, 113, 213-234. [CrossRef]

98. Orditura, M.; Galizia, G.; Sforza, V.; Gambardella, V.; Fabozzi, A.; Laterza, M.M.; Andreozzi, F.; Ventriglia, J.; Savastano, B.; Mabilia, A.; et al. Treatment of gastric cancer. World J. Gastroenterol. 2014, 20, 1635-1649. [CrossRef]

99. Lackey, A.; Donington, J. Surgical management of lung cancer. Semin. Intervent. Radiol. 2013, 30, $133-140$. [CrossRef] 
100. Rentsch, M.; Schiergens, T.; Khandoga, A.; Werner, J. Surgery for colorectal cancer - Trends, developments, and future perspectives. Visc. Med. 2016, 32, 184-191. [CrossRef]

101. Tohme, S.; Simmons, R.L.; Tsung, A. Surgery for Cancer: A Trigger for Metastases. Cancer Res. 2018, 77, 1548-1552. [CrossRef] [PubMed]

102. Alieva, M.; van Rheenen, J.; Broekman, M.L.D. Potential impact of invasive surgical procedures on primary tumor growth and metastasis. Clin. Exp. Metastasis 2018, 35, 319-331. [CrossRef] [PubMed]

103. Martin, T.; Ye, L.; Sanders, A.; Lane, J.; Jiang, W. Cancer Invasion and Metastasis: Molecular and Cellular Perspective. Metastatic Cancer Clin. Biol. Perspect. 2014, 9, 1-28.

104. Hanahan, D.; Weinberg, R.A. Hallmarks of cancer: The next generation. Cell 2011, 144, 646-674. [CrossRef] [PubMed]

105. Wienberg, D.H.R.A. The Hallmarks of Cancer. Cell 2000, 100, 57-70.

106. Peinado, H.; Lavotshkin, S.; Lyden, D. The secreted factors responsible for pre-metastatic niche formation: Old sayings and new thoughts. Semin. Cancer Biol. 2011, 21, 139-146. [CrossRef] [PubMed]

107. Aplin, A.E.; Howe, A.; Alahari, S.K.; Juliano, R.L. Signal transduction and signal modulation by cell adhesion receptors: The role of integrins, cadherins, immunoglobulin-cell adhesion molecules, and selectins. Pharmacol. Rev. 1998, 50, 197-263.

108. Christofori, G.; Semb, H. The role of the cell-adhesion molecule E-cadherin as a tumour-suppressor gene. Trends Biochem. Sci. 1999, 24, 73-76. [CrossRef]

109. Cavallaro, U.; Christofori, G. Cell adhesion and signalling by cadherins and Ig-CAMs in cancer. Nat. Rev. Cancer 2004, 4, 118-132. [CrossRef]

110. Johnson, J.P. Cell adhesion molecules of the immunoglobulin supergene family and their role in malignant transformation and progression to metastatic disease. Cancer Metastasis Rev. 1991, 10, 11-22. [CrossRef]

111. Varner, J.A.; Cheresh, D.A. Integrins and cancer. Curr. Opin. Cell Biol. 1996, 8, 724-730. [CrossRef]

112. Werb, Z. ECM and cell surface proteolysis: Regulating cellular ecology. Cell 1997, 91, 439-442. [CrossRef]

113. Karnoub, A.E.; Dash, A.B.; Vo, A.P.; Sullivan, A.; Brooks, M.W.; Bell, G.W.; Richardson, A.L.; Polyak, K.; Tubo, R.; Weinberg, R.A. Mesenchymal stem cells within tumour stroma promote breast cancer metastasis. Nature 2007, 449, 557-563. [CrossRef] [PubMed]

114. Kessenbrock, K.; Plaks, V.; Werb, Z. Matrix Metalloproteinases: Regulators of the tumor. Cell 2010, 141, $52-67$. [CrossRef] [PubMed]

115. Qian, B.; Pollard, J.W. Macrophage Diversity Enhances Tumor Progression and Metastasis. Cell 2010, 141, 39-51. [CrossRef] [PubMed]

116. Wang, Q.; Qian, J.; Wang, F.; Ma, Z. Cellular prion protein accelerates colorectal cancer metastasis via the Fyn-SP1-SATB1 axis. Oncol. Rep. 2012, 28, 2029-2034. [CrossRef]

117. Du, L.; Rao, G.; Wang, H.; Li, B.; Tian, W.; Cui, J.; He, L.; Laffin, B.; Tian, X.; Hao, C.; et al. CD44-positive cancer stem cells expressing cellular prion protein contribute to metastatic capacity in colorectal cancer. Cancer Res. 2013, 73, 2682-2694. [CrossRef]

118. Chieng, C.K.L.; Say, Y.H. Cellular prion protein contributes to LS $174 \mathrm{~T}$ colon cancer cell carcinogenesis by increasing invasiveness and resistance against doxorubicin-induced apoptosis. Tumor Biol. 2015, 36, 8107-8120. [CrossRef]

119. Wang, Y.; Yu, S.; Huang, D.; Cui, M.; Hu, H.; Zhang, L.; Wang, W.; Parameswaran, N.; Jackson, M.; Osborne, B.; et al. Cellular Prion Protein Mediates Pancreatic Cancer Cell Survival and Invasion through Association with and Enhanced Signaling of Notch1. Am. J. Pathol. 2016, 186, 2945-2956. [CrossRef]

120. Yang, L.; Gao, Z.; Hu, L.; Wu, G.; Yang, X.; Zhang, L.; Zhu, Y.; Wong, B.S.; Xin, W.; Sy, M.S.; et al. Glycosylphos-phatidylinositol anchor modification machinery deficiency is responsible for the formation of pro-prion protein ( $\mathrm{PrP})$ in BxPC-3 protein and increases cancer cell motility. J. Biol. Chem. 2016, 291, 3905-3917. [CrossRef]

121. Li, C.; Yu, S.; Nakamura, F.; Yin, S.; Xu, J.; Petrolla, A.A.; Singh, N.; Tartakoff, A.; Abbott, D.W.; Xin, W.; et al. Binding of pro-prion to filamin A disrupts cytoskeleton and correlates with poor prognosis in pancreatic cancer. J. Clin. Invest. 2009, 119. [CrossRef] [PubMed]

122. Ke, J.; Wu, G.; Zhang, J.; Li, H.; Gao, S.; Shao, M.; Gao, Z.; Sy, M.S.; Cao, Y.; Yang, X.; et al. Melanoma migration is promoted by prion protein via Akt-hsp27 signaling axis. Biochem. Biophys. Res. Commun. 2020, 523, 375-381. [CrossRef] [PubMed] 
123. Pan, Y.; Zhao, L.; Liang, J.; Liu, J.; Shi, Y.; Liu, N.; Zhang, G.; Jin, H.; Gao, J.; Xie, H.; et al. Cellular prion protein promotes invasion and metastasis of gastric cancer. FASEB J. 2006, 20, 1886-1888. [CrossRef] [PubMed]

124. Gil, M.; Kim, Y.K.; Kim, K.E.; Kim, W.; Park, C.S.; Lee, K.J. Cellular prion protein regulates invasion and migration of breast cancer cells through MMP-9 activity. Biochem. Biophys. Res. Commun. 2016, 470, $213-219$. [CrossRef] [PubMed]

125. Cheng, Y.; Tao, L.; Xu, J.; Li, Q.; Yu, J.; Jin, Y.; Chen, Q.; Xu, Z.; Zou, Q.; Liu, X. CD44/Cellular prion protein interact in multidrug resistant breast cancer cells and correlate with responses to neoadjuvant chemotherapy in breast cancer patients. Mol. Carcinog. 2014, 53, 686-697. [CrossRef]

126. Mangé, A.; Milhavet, O.; Umlauf, D.; Harris, D.; Lehmann, S. PrP-dependent cell adhesion in N2a neuroblastoma cells. FEBS Lett. 2002, 514, 159-162. [CrossRef]

127. Dillekås, H.; Rogers, M.S.; Straume, O. Are $90 \%$ of deaths from cancer caused by metastases? Cancer Med. 2019, 8, 5574-5576. [CrossRef]

(C) 2020 by the authors. Licensee MDPI, Basel, Switzerland. This article is an open access article distributed under the terms and conditions of the Creative Commons Attribution (CC BY) license (http://creativecommons.org/licenses/by/4.0/). 